\title{
PENGGUNAAN METODE BERCERITA DENGAN MEDIA GAMBAR DALAM UPAYA MENINGKATKAN KEMAMPUAN BERBAHASA DAN SIKAP MANDIRI ANAK TK B DEWI SARTIKA SINTANG
}

\author{
Sarayati \\ STKIP Persada Khatulistiwa Sintang,Jl.Pertamina KM 4, Sengkuang \\ Email: sarayatispd@yahoo.com
}

\begin{abstract}
Abstrak
Penelitian ini bertujuan untuk menganalisis dan mendeskripsikan peningkatan kemampuan berbahasa dan sikap mandiri anak melalui penggunaan metode bercerita dengan media gambar. Penelitian ini dilaksanakan di TK B Dewi Sartika Sintang. Subjek penelitian berjumlah 20 orang anak. Penelitian ini merupakan penelitian tindakan kelas yang dilaksanakan persiklus. Metode pengumpulan data yang digunakan metode observasi dengan instrumen kemampuan berbahasa dan sikap mandiri, analisis data dilakukan secara deskriptif dengan kriteria ketuntasan adalah $\geq 65$. Penelitian ini dilaksanakan 2 siklus,hasil penelitian menunjukkan akhir siklus I kemampuan berbahasa anak yang mencapai ketuntasan sebanyak 45\%,meningkat diakhir siklus II 99\%, dan sikap mandiri siklus I mencapai ketuntasan sebanyak 40\%, meningkat di akhir siklus II mencapai 90\%. Ini berarti kegiatan pembelajaran menggunakan metode bercerita dengan media gambar secara signifikan dapat meningkatkan kemampuan berbahasa dan sikap mandiri anak sesuai indikator yang diharapkan.
\end{abstract}

Kata Kunci: Metode Bercerita, Media Gambar, Kemampuan Berbahasa, Sikap Mandiri

\begin{abstract}
This study aimed at analyzing and describing the kindergarten students' language ability and self independence by using pictures supporting story-telling method. It was carried out in Group A in TK Dewi Sartika Sintang. The respondents were 20 students. The research method used was classroom action research that was conducted in cycles. The data were collected through observation method by using language ability and selfindependence instruments. To analyze the data, the researcher used descriptive technique, and the standard of minimum completeness of mastery learning was $\geq 65$. The research was conducted in two cycles. At the end of the first cycle, it revealed that the students' language ability that achieved the minimum completeness was 45\% and it improved to be $99 \%$ at the end of the second cycle. Moreover, at the end of the first cycle, it showed that the percentage of students' self-independence that reached the minimum completeness was $40 \%$ and it also improved to be $90 \%$ at the end of the second cycle. In conclusion, the findings of the study indicated that the use of pictures supporting story-telling method significantly enhanced the kindergarten students' language ability and the self-independence.
\end{abstract}

Keywords: Pictures, Story Telling Method, Language Ability, Self-Independence. 


\section{PENDAHULUAN}

Taman Kanak-Kanak adalah pendidikan untuk anak usia dini yang dilaksanakan melalui jalur formal bagi anak yang berusia 4-6 tahun. Usia tersebut merupakan masa emas (golden age) bagi anak dalam menerima berbagai upaya pengembangan seluruh potensi dirinya. Masa tersebut adalah masa terjadinya kematangan fungsi fisik dan psikis yang merespons stimulasi yang diberikan oleh lingkungan untuk mendasari pengembangan kemampuan dasar yaitu: berbahasa, kognitif, fisik/ motorik dan sikap mandiri anak (PermendiknasNomor 58, 2009). Pada anak, istilah kemandirian umumnya dikaitkan dengan kemampuan untuk melakukan segala sesuatunya sendiri. Apakah itu memakai baju sendiri, menalikan sepatunya sendiri, makan sendiri, dan melakukan hal-hal yang sederhana sendiri tanpa harus tergantung pada bantuan orang lain (Yusuf Syamsu: 2009). Sikap mandiri anak harus dibina sejak usia dini, seandainya sikap mandiri anak ditanamkan setelah anak besar, sikap mandiri itu akan menjadi tidak utuh secara alamiah anak sudah mempunyai dorongan untuk mandiri atas dirinya sendiri. Mereka terkadang lebih senang untuk biasa mengurus dirinya sendiri dari pada dilayani. Sayangnya orang tua sering menghambat keinginannya dan dorongan untuk menjadi mandiri. Sikap mandiri yang diajar kan pada anak sejak dini akan membuatnya, dapat mengatur waktu kegiatannya sendiri dan membuat anak terbiasa me nolong orang lain serta lebih bisa menghargai orang lain. Oleh karena itu sikap mandiri pada anak sangat diperlukan karena dengan kemandirian, anak bisa menjadi lebih bertanggung jawab dalam memenuhi kebutuhannya (Sidharto\&Izzaty,2004). Selain mengembangkan sikap mandiri anak pengembangan kemampuan berbahasa anak juga perlu dikembangkan karena kemampuan berbahasa pada dasarnya merupakan rangkaian bunyi yang melambangkan pikiran, perasaan serta sikap (Akhadiah, dkk, 2000: 2).

Pengajaran bahasa Indonesia pada hakikatnya merupakan salah satu sarana mengupayakan pembinaan dan pengem bangan bahasa Indonesia secara terarah. Pengajaran bahasa di TK memiliki arti dan peran penting dalam membentuk kebiasaan, sikap, dan kemampuan dasar yang diperlu kan anak serta membantu anak mengembangkan keterampilan berbahasa yang dimiliki. Keterampilan berbahasa tersebut meliputi empat aspek yaitu: menyimak, berbicara, membaca, dan menulis (Tarigan, 2008). Kemampuan berbicara adalah kemampuan mengucapkan bunyi-bunyi artikulasi atau kata-kata untuk 


\section{Sarayati}

mengekspresikan, menyatakan atau menyampaikan pikiran, gagasan, dan perasaan (Tarigan, 2008: 16). Kegiatan berbicara dalam kehidupan sehari-hari merupakan suatu kebutuhan manusia sebagai makhluk sosial untuk melakukan komunikasi dengan orang lain. Kegiatan bercerita merupakan bagian dari kemampuan berbicara. Kegiatan bercerita memiliki beberapa manfaat bagi siswa yaitu dapat memperkaya kosa-kata, memperbaiki kalimat serta melatih keberanian anak dalam berkomunikasi. Bercerita juga dapat didefinisikan sebagai peng-hubung sebuah cerita kepada satu atau lebih pendengar melalui suara dan gerakan (Santosa, 2009). Bercerita adalah seni menggunakan bahasa, vokalisasi, dan atau gerakan fisik dan isyarat untuk mengungkapkan unsur-unsur dan gambaran dari sebuah cerita kepada sesuatu yang spesifik, kehidupan penonton. Untuk itu, agar cerita tersebut dapat didengar dengan baik oleh pendengar selain suara atau vokal diperlukan pula media untuk mendukung pencerita dalam melakukan gerakan saat bercerita. Media dapat digunakan sebagai penghubung atau pembawa pesan dari sumber pesan kepada penerima pesan. Anitah (2009) menyatakan bahwa media merupakan bentuk jamak dari kata medium, yang berarti sesuatu yang terletak di tengah (antara dua pihak atau kutub) atau suatu alat. Dengan kata lain media dijadikan sebagai perantara atau penghubung antara dua pihak, yaitu sumber pesan dengan penerima pesan atau informasi.

Dalam pembelajaran bercerita seharusnya guru tidak memakai cara yang monoton hanya menyuruh anak berdiri di depan kelas untuk bercerita atau mendengarkan cerita dari guru tanpa ada pesan lain, tanpa ada variasi dalam pembelajaran. Hal tersebut dapat menyebabkan anak kurang tertarik pada proses pembelajaran dan hanya akan menimbul kan kejenuhan serta kebosanan dalam diri anak karena pembelajaran lebih banyak didominasi guru tanpa melibat kan anak secara aktif. Selain itu, terkadang anak masih kurang berani ketika tampil di depan kelas sehingga keterampilan bercerita yang dimiliki anak menjadi rendah. Untuk mempermudah anak dalam menerima pembelajaran dan menarik minat anak untuk mendengarkan cerita guru sehingga kemampuan berbahasa anak menjadi meningkat.

Kemampuan berbahasa memiliki peran sentral dalam perkembangan intelektual, sosial, dan emosional anak, dan merupakan penunjang keberhasilan dalam mempelajari semua bidang studi pada pendidikan lebih tinggi. Pembelajaran bahasa diharapkan membantu peserta didik mengenal dirinya, budayanya, dan budaya 
orang lain, mengemuka kan gagasan dan perasaan, berpartisipasi dalam masyarakat yang menggunakan bahasa tersebut, dan menemukan serta menggunakan ke mampuan analitis dan imaginatif yang ada dalam dirinya (Siskandar, 2003). Kemampuan berbahasa di TK diarahkan untuk meningkatkan kemampuan anak untuk berkomunikasi dalam bahasa Indonesia dengan baik dan benar. Dalam berbahasa, ada empat kemampuan berbahasa, yaitu kemampuan mendengar, berbicara, membaca, dan menulis. Sesuai dengan perkembangan mental anak, maka pada usia TK anak hanya dituntut untuk mampu mendengar dan berbicara secara baik dan benar sesuai dengan perkembangan usianya. Pada kemampuan mendengar kan, anak sudah akan dapat mendengarkan bunyi-bunyian yang dihasilkan oleh apapun yang ada di sekitarnya. Hal ini dimulai dari ketika anak baru lahir, apa yang didengarkan tidak dapat langsung dikenali. Ada proses pengenal an terhadap apa, dan siapa yang mengeluarkan bunyi, ini akan menjadi luar biasa, terasah dengan baik di sepanjang hidup anak sehingga anak dapat membedakan siapa atau apa yang mengeluarkan bebunyian itu. Hal ini diperolehnya sebagai bentuk peniruan bunyi bahasa (Depdiknas, 2006). Melihat pentingnya perkembangan berbahasa pada anak, maka pemerintah merancang kurikulum TK yang mengarahkan agar para guru TK dapat memotivasi anak, agar anak sejak dini mampu mendengarkan dan berbahasa secara baik dan benar, serta senang belajar menulis meskipun masih dalam bentuk gambar-gambar atau simbulsimbul yang dapat mengekspresikan minat dan kemampuannya. Tetapi pada kenyataannya pengajaran bahasa saat ini kurang mendapat perhatian. Ketidak puasan guru belakangan ini muncul terhadap kemampuan berbahasa dan sikap mandiri anak yang ditunjukkan anak kurang optimal. Pelajaran berbahasa kurang ditangani secara sungguh-sungguh yang meng-akibatkan kemampuan berbahasa anak menjadi kurang memadai. Pengajaran berbahasapun masih didominasi oleh aspek-aspek pengetahuan. Anak lebih banyak belajar tentang bahasa, bukan belajar berbahasa sehingga kemampuan anak untuk menyusun sebuah kalimat sederhana belum memadai. Dasar utama berbahasa adalah melalui pengalamanpengalaman berkomunikasi yang kaya. Pengalaman-pengalaman yang kaya itu akan menunjang faktor-faktor bahasa yang lain yaitu: mendengarkan, berbicara, membaca, dan menulis (Slamet, 2007).

Berdasarklan permasalahan yang diuraian di atas, jelas terlihat harapanharapan yang diinginkan dalam 


\section{Sarayati}

pembelajaran di TK terutama dalam peningkatan kemampuan berbahasa dan sikap mandiri anak, tetapi kenyataan atau realita yang terjadi pada pembelajaran di TK saat ini belum sesuai harapan. Begitu juga halnya dengan kegiatan bercerita dengan media gambar jarang diberikan, sehingga anak kurang tertarik untuk mengikuti pembelajaran, karena kegiatan bersifat menotun, begitu juga guru jarang mengajak anak anak bercerita karena tidak terbiasa, guru merasa sulit membawakan cerita, sehingga lebih baik guru mengajak anak-anak berhitung, menulis dan mengajarkan membaca awal. Pengetahuan guru didalam bercerita sangat kurang dan minim. Padahal kegiatan bercerita merupakan kegiatan yang menyenangkan anak apalagi didukung oleh media yang menarik. Demikian pula kenyataannya pada kelas B TK Dewi Sartika Sintang, sikap mandiri dan kemampuan berbahasa anak secara umum masih rendah. Dengan demikian apabila sikap mandiri dan kemampuan berbahasa anak ini mengalami masalah, dan tidak ditangani secara serius, tentu akan berdampak pada tujuan pendidikan yang lain yaitu tidak dapat mengembangkan berbagai potensi anak. Supaya sikap mandiri dan kemampuan berbahasa anak berkembang sesuai dengan aspek-aspek perkembangan anak, maka pemilihan metode pembelajaran yang paling tepat dalam pengembangan sikap mandiri dan kemampuan berbahasa anak di TK adalah dengan menerapkan metode bercerita. Karena metode bercerita merupakan salah satu metode pembelajaran yang memberkan pengalaman belajar bagi anak TK dengan membawakan cerita kepada anak secara lisan. (Depdiknas, 2007: 32).

Berdasarkan uraian di atas penulis merasa tertarik untuk meng-angkat dalam suatu penelitian tindakan dengan judul "Penggunaan Metode Bercerita Dengan Media Gambar Dalam Upaya Meningkatkan Kemampuan Berbahasa dan Sikap Mandiri Anak kelas B TK Dewi Sartika Sintang Tahun Ajaran 2018/2019. Dengan menerapkan metode bercerita media gambar, kegiatan pembelajaran akan menjadi menarik sehingga kemampuan berbahasa dan sikap mandiri anak akan menjadi me-ningkat. Penelitian ini dilakukan untuk menunjukkan bukti secara ilmiah yang didukung oleh data emperis tentang keunggulan dari metode dan media pembelajaran.

\section{METODE PENELITIAN}

Metode penelitian ini merupakan penelitian tindakan kelas yang dilaksanakan dalam dua siklus. Penelitian Tindakan Kelas yang dilaksanakan di TK Dewi Sartika Sintang melibatkan guru 


\section{Sarayati}

sebagai mitra dalam pelaksanaan metode bercerita. Peneliti terjun langsung sebagai observer yang melakukan pengumpulan data dengan metode triangulasi data. Metode pengumpulan data yang digunakan panduan observasi dan wawancara serta beberapa dokumen yang diperkukan. Hasil pengamatan dengan instrumen kemampuan berbahasa dan sikap mandiri, analisis data dilakukan secara deskripsi dan analisis dengan kriteria ketuntasan $\geq 65$ Penelitian ini dilaksanakan di kelas B TK Dewi Sartika Sintang. Subjek penelitian berjumlah 20 orang anak.

\section{HASIL PENELITIAN DAN PEMBAHASAN}

Hasil penelitian menunjukkan bahwa penerapan metode bercerita dengan media gambar dapat meningkatkan kemampuan berbahasa anak dan sikap mandiri anak pada kelas B TK Dewi Sartika Sintang. Hal ini disebabkan karena bagi anak usia TK mendengarkan cerita yang menarik dan dibantu dengan gambargambar sesuai dengan cerita yang diceritakan merupakan kegiatan yang menyenangkan, apalagi gambar yang dipakai media oleh guru dalam bercerita adalah gambar-gambar yang berwarna dan diambil dari buku-buku cerita dan gambar yang dipilih oleh guru sendiri. Kegiatan bercerita dengan media gambar memberi pengalaman belajar yang sangat lengkap yaitu untuk berlatih mendengarkan cerita yang diceritakan oleh guru, melatih penglihatan untuk melihat gambar yang ditampilkan oleh guru, serta melatih daya ingat anak untuk mengingat gambargambar yang diperlihatkan sehingga cepat meresap di pikiran anak. Melalui mendengar, melihat, anak memperoleh bermacam informasi tentang pengetahuan, nilai dan sikap mandiri yang diperankan oleh tokoh dalam cerita, anak mampun memetik ikmahnya untuk dihayati dan diterap kan dalam kehidupan sehari-hari melalui pesan moral yang disampaikan oleh guru saat bercerita.

Kegiatan pembelajaran dengan menggunakan metode bercerita dengan media gambar memberikan pengalaman belajar yang unik dan menarik perasaan, membangkitkan semangat dan menimbulkan kesenangan tersendiri, maka kegiatan bercerita memungkinkan pengembangan aspek kemampuan anak didalam mengungkapkan bahasa, mampu memahami bahasa, dan keaksaraan. Begitu juga pada aspek sikap mandiri anak yaitu memiliki sikap percaya diri, sikap disiplin, dan sikap bertanngung jawab yang ditunjukkan oleh tokoh-tokoh dalam cerita melalui media gambar. Dari hasil pelaksanaan tindakan menggunakan meode bercerita dengan media gambar dalam kegiatan pembelajaran, diperoleh masukan 


\section{Sarayati}

pada hal-hal sebagai berikut: 1) Penggunaan metode bercerita dengan media gambar ini, dalam menerapannya memerlukan kesabaran, ketekunan dan kerja keras serta komitmen yang tinggi bagi seorang guru, 2) Peneliti memerlukan persiapan yang matang, terutama dalam menyiapkan media gambar, sarana dan prasarana yang dibutuhkan sesuai cerita yang akan diceritakan, 3) Memerlukan motivasi yang kuat dari seorang guru untuk memulai metode ini. Perlu dilakukan pembinaan dan pemantapan terhadap para guru agar memiliki kemauan dan kemampuan dalam menerapkan metode bercerita dengan media gambar, dan berusaha membuat gambar sendiri dan menampilkan gambar sesuai karakter anak yang mudah dimengerti oleh anak, 4) Penggunaan metode bercerita dengan media gambar dapat memberikan solusi bagi guru yang ingin meningkat kan kinerjanya. Hasil penelitian menunjukkan bahwa penerapan metode bercerita dengan media gambar dapat meningkatkan kemampuan berbahasa dan sikap mandiri anak pada kelas B TK Dewi Sartika Sintang.

Dari hasil analisis selain meningkatkan kemampuan berbahasa, hasil analisis awal refleksi nilai rata-rata kemampuan berbahasa anak juga mampumeningkatkan aspek kemampuan anak didalam mengungkapkan bahasa dengan nilai rata-rata 40.30 dengan klasifikasi kurang, kemampuan anak didalam menerima bahasa 41.51 dengan klasifikasi kurang, sedangkan aspek keaksaraan 40.14 dengan klasifikasi kurang. Akhir siklus I kemampuan anak didalam meng-ungkapkan bahasa 56.66 dengan klasifikasi cukup, kemampuan anak didalam menerima bahasa 56.47 dengan klasifikasi cukup, aspek keaksaraan 58.09 dengan klasifikasi cukup. Akhir siklus II pada aspek kemampuan anak didalam mengungkapkan bahasa 76.66 dengan klasifikasi sangat baik, kemampuan anak didalam menerima bahasa 76.33 dengan klasifikasi sangat baik, aspek keaksaraan 77.65 dengan klasifikasi sangat baik. Sedangkan nilai rata-rata awal refleksi adalah 41.31 dengan klasifikasi kurang, akhir siklus I dengan nilai rata-rata 57.07 dengan klasifikasi cukup dan akhir siklus II dengan nilai rata-rata 76.54 dengan klasifikasi sangat baik.

Dengan demikian kegiatan pembelajaran dengan menggunakan metode bercerita dengan media gambar dapat meningkatkan kemampuan berbahasa anak karena metode bercerita dengan media gambar dapat memberikan pengalaman belajar yang unik dan mampu menarik perasaan anak, serta mampu membangkitkan semangat dan 
menimbulkan kesenangan tersendiri, maka kegiatan bercerita dengan media gambar dapat meningkatkan kemampuan berbahasa anak dengan aspek kemampuan mengungkapkan bahasa, mampu memahami bahasa, dan keaksaraan. Begitu juga pada aspek sikap mandiri anak yaitu memiliki sikap percaya diri, sikap disiplin, dan sikap bertanngung jawab yang ditunjukkan oleh tokoh-tokoh dalam cerita melalui media gambar. Penelitian ini merupakan penelitian tindakan kelas yang dilakukan di kelas B TK Dewi Sartika Sintang. Hasil penelitian ini menemukan bahwa kemampuan menyimak anak dapat meningkat, setelah diterapkan metode bercerita dalam pengajaran. Selain kemampuan menyimak, keaktifan anak juga meningkat setelah diterapkan metode bercerita dalam pengajaran di TK. Implikasi dan relevan si dengan penelitian ini adalah bahwa dengan adanya peningkatan kemampu an menyimak anak melalui penerapan metode bercerita, maka diasumsikan bahwa melalui penerapan metode bercerita secara umum akan mampu meningkatkan kemampuan berbahasa anak. Karena kemampuan menyimak merupakan salah satu aspek dari kemampuan berbahasa selain kemampuan berbicara yang dituntut pada pengajaran di TK. Keberhasilan penelitian ini juga didukung oleh penelitian dari Nurul
Octavia (2011) dalam Jurnal penelitian PAUD Volume 1, No.1, tahun 2011, dengan judul penelitian analisis kemam puan penguasaan kosa kata baru pada anak POS PAUD Mutiara Semarang melalui metode bercerita. Penelitian yang dilakukan ini merupakan penelitian jenis kualitatif yang difokuskan pada satu fenomena saja yang akan ditelaah secara mendalam. Dengan demikian melalui implementasi metode bercerita dapat meningkatkan kemampuan berbahasa anak. Jadi penggunaan metode bercerita dengan media gambar dalam pengajaran di TK, menunjukkan bahwa secara empirik kemampuan berbahasa anak dapat meningkat setelah diterap kan metode bercerita dengan media gambar terbukti secara nyata. Dengan demikian penggunaan metode bercerita dengan media gambar dapat meningkat kan kemampuan berbahasa anak kelas B TK Dewi Sartika Sintang.

Penggunaan metode bercerita dengan media gambar juga dapat meningkatkan sikap mandiri anak kelas B TK Dewi Sartika Sintang, dari 20 orang jumlah anak dari refleksi awal atau sebelum tindakan sikap mandiri anak dengan klasifikasi baik 3 orang anak (15\%), cukup 7 orang anak (35\%), dan kurang 10 orang anak (50\%), akhir siklus I anak dengan klasifikasi baik 8 orang (40\%) 
cukup 12 orang $(60 \%)$ dan tidak ada anak dengan klasifikasi kurang. Dan akhir siklus II anak dengan klasifikasi sangat baik 13 orang $(60 \%)$ baik 8 orang $(40 \%)$ tidak ada anak dengan klasifikasi cukup dan kurang.

Dari hasil analisis, selain meningkatkan sikap mandiri anak, juga terjadi peningkatan pada aspek sikap percaya diri anak ini terbukti hasil analisis awal refleksi sebelum tindakan dengan nilai rata-rata 40.09 dengan klasifikasi kurang, akhir siklus I sengan nialai rata-rata 54.99 dengan klasifikasi cukup, akhir siklus II yaitu 77.77 dengan klasifikasi sangat baik. Pada aspek sikap disiplin sebelum tindakan 41.16 dengan klasifikasi kurang, akhir siklus I yaitu 56.10 dengan klasifikasi cukup, akhir siklus II yaitu 76.65 dengan klasifikasi sangat baik. Sedang kan pada aspek sikap bertangung jawab awal refleksi 40.05 dengan klasifikasi kurang, 56.10 diakhir siklus I dengan klasifikasi cukup, 76.65 diakhir siklus II dengan klasifikasi sangat baik. Pada aspek sikap ber tanggung jawab sebelum tindakan kegiatan awal refleksi yaitu 43.05 dengan klasifikasi kurang, 52.77 dengan klasifikasi cukup pada akhir siklus I sedangkan 78.33 dengan klasifikasi sangat baik pada akhir siklus II.

Sedangkan hasil analisis dari awal refleksi nilai rata-rata sikap mandiri anak 41.10 dengan klasifikasi kurang, 54.64 pada akhir siklus I dengan klasifikasi cukup, dan akhir siklus II yaitu 77.58 dengan klasifikasi sangat baik. Penggunaan metode bercerita dapat meningkatkan sikap mandiri anak karena dapat memberikan pengalaman belajar yang unik dan mampu menarik perasaan anak, serta mampu membangkitkan semangat dan menimbulkan kesenangan tersendiri, maka kegiatan bercerita dengan media gambar dapat meningkatkan sikap mandiri anak pada aspek memiliki sikap percaya diri, sikap disiplin, dan sikap bertangungjawab yang ditunjukkan oleh tokoh-tokoh dalam cerita melalui media gambar. Pemanfaatan akan media gambar akan sangat penting baik bagi guru maupun anak, karena media mem punyai fungsi penting dalam pendidikan antara lain yaitu sebagai media instruksional edukatif sangat dipenga-ruhi oleh ruang, waktu, pendengaran serta sarana dan prasarana yang teredia, disamping itu sifat dari media instruksional edukatif. Fungsi media pembelajaran menyampaikan informasi dalam proses belajar mengajar, memperjelas informasi pada waktu tatap muka dalam proses belajar mengajar. Dengan menggunakan media intruksional edukatif secara tepat, dapat menimbulkan semangat yang lesu menjadi bergairah, pelajaran yang langsung menjadi lebih hidup, mudah dicerna dan tahan lama dalam menyerap pesan-pesan. 
Dengan demikian gambar menjadi media pembelajaran yang utama dalam meningkatkan sikap mandiri anak. Pemilihan metode ber cerita didalam kegiatan pembelajaran dapat menarik minat anak didalam mendengarkan cerita yang diceritakan oleh guru dengan media gambar, anak dapat mengayati dan peranperan yang ada pada gambar yang diceritakan, melalui perbuatan, menunjukkan sikap-sikap bahwa dengan menggunakan metode bercerita dengan media gambar sebagai sumber belajar dan sumber cerita akan dapat meningkat kan sikap mandiri anak. Pengembangan sikap mandiri ini akan mudah berkembang bagi anak TK asalkan guru pintar memilih metode pengajaran. Metode yang sangat cocok diterapkan adalah metode bercerita. Metode bercerita merupakan salah satu pemberian pengalaman belajar bagi anak TK dengan membawakan cerita kepada anak secara lisan.

Dengan metode bercerita anak-anak akan kembali pada dunia kehidupannya yang penuh suka cita, karena menimbulkan perasaan alami mereka seperti gembira, lucu, dan mengasyikkan. Dunia kehidupan anak-anak itu dapat berkaitan dengan lingkungan keluarga, sekolah, dan luar sekolah, yang bersifat unik dan menarik, yang menggetarkan perasaan anak, dan memotivasi anak untuk mendengarkan cerita itu sampai tuntas, sehingga mampu mengambil pesan-pesan moral yang disampaikan oleh guru saat bercerita, dan mampu memotivasi anak agar mampu memiliki sikap mandiri.

Keberhasilan penelitian ini juga didukung oleh penelitian dari Riati (2010) dengan judul penelitiannya "Pengaruh Pembelajaran Kontekstual dan Sikap Kemandirian Anak Terhadap Kreativitas Anak Kelompok B TK Ganda Kerta Kumara Denpasar" Penelitian ini merupakan penelitian eksperimen yaitu membandingkan model pembelajaran kontekstual dengan pembelajaran langsung dalam kegiatan pembelajaran yang dapat meningkatkan kreativitas anak dengan dipengaruhi oleh sikap kemandirian anak. Hasil penelitian ini menemukan bahwa kreativitas anak yang mengikuti kegiatan dengan model pembelajaran kontekstual lebih tinggi daripada anak yang mengikuti pelajaran dengan model pembelajaran langsung, pada sikap mandiri tinggi anak yang mengikuti pembelajaran dengan model pembelajaran kontekstual lebih tinggi daripada anak yang mengikuti pelajaran dengan model pembelajaran langsung sedangkan pada anak yang sikap mandiri rendah terjadi sebaliknya. Terdapat pengaruh interaksi antara model pembelajaran dengan sikap mandiri terhadap kreativitas anak. Implikasi dari 
penelitian ini adalah: model pembelajaran kontekstual merupakan salah satu alternatif model pembelajaran yang dapat meningkatkan kreativitas, model

Berdasarkan uraian di atas, tampak bahwa terjadi peningkatan kemampuan berbahasa dan sikap mandiri anak melalui penggunaan metode bercerita dengan media gambar pada anak kelas B TK Dewi Sartika Sintang. Jadi pengguna an metode bercerita dengan media gambar dalam pengajaran di TK, menunjukkan bahwa secara empirik sikap mandiri anak dapat berkembang setelah diterapkan metode bercerita dengan media gambar terbukti secara nyata. Dengan demikian penggunaan metode bercerita dengan media gambar dapat meningkatkan sikap mandiri anak kelas B TK Dewi Sartika Sintang.

\section{PENUTUP}

Sikap mandiri adalah suatu sikap individu yang diperoleh secara kumulatif selama perkembangan, dimana individu akan terus belajar untuk bersikap mandiri dalam menghadapi berbagai situasi lingkungan, sehingga individu pada akhirnya akan mampu berfikir dan bertindak sendiri dengan kemandiriannya Tjandraningtyas, (Riati, 2010). Sedangkan perkembangan bahasa di TK diarahkan untuk meningkatkan kemampuan anak untuk berkomunikasi dalam bahasa pembelajaran kontekstual dan model pembelajaran langsung dalam penerapannya harus mempertimbangkan sikap mandiri anak Indonesia secara sederhana dengan baik dan benar. Sesuai dengan perkembangan mental dan kognitif anak, maka pada usia TK anak hanya dituntut untuk mampu mendengarkan dan berbicara secara baik dan benar sesuai dengan perkembangan usianya. Dasar utama berbahasa adalah melalui pengalaman-pengalaman berkomunikasi. Sesuai analisis hasil tindakan dan pembahasan seperti yang telah dipaparkan pada bagian sebelumnya, maka ada beberapa hal sebagai berikut.

Dalam penelitian ini ditemukan ketuntasan peningkatan kemampuan berbahasa akhir siklus I mencapai $45 \%$, meningkat diakhir siklus II 99\%, dan sikap mandiri akhir siklus I men-capai ketuntasan 40\%, meningkat diakhir siklus II mencapai 90\%. Ini berarti kegiatan pembelajaran menggunakan metode bercerita dengan media gambar secara signifikan dapat meningkatkan kemampuan berbahasa dan sikap mandiri anak sesuai indikator yang diharapkan. Selain itu terjadi juga peningkatan pada aspek mengungkapkan bahasa, menerima bahasa dan keaksaraan secara signifikan.

Jadi penggunaan metode bercerita dengan media gambar dalam kegiatan 
pengajaran di TK, menunjuk kan bahwa secara empirik dapat meningkatkan kemampuan bahasa dan sikap mandiri anak terbukti secara nyata pada anak kelas B TK Dewi Sartika. Dengan demikian hipotesis tindakan dapat teruji dan terjawab.

\section{DAFTAR PUSTAKA}

Akhadiah M.K.S. Arsjad, M.G., Ridwan, S.H., Zulfahnur, \& Mukti. 2000. Bahasa Indonesia 1. Jakarta: Departemen Pendidikan dan Kebudayaan Direktorat Jenderal Pendidikan Tinggi Proyek Pembinaan Tenaga Kependidikan.

\section{Buletin PAUD. Jurnal Ilmiah Anak Usia}

Dini. Menu Pembelajaran PADU, Vol.2 No.01. april 2003.

Depdiknas. 2006a. Petunjuk Pelaksana an Proses Belajar Mengajar. Jakarta: Proyek pengadaan sarana dan prasarana peningkatan mutu dikmenum

$\begin{array}{cr}\text { Petunjuk } & \text { Teknis } \\ \text { Penyelengaraan Pendidikan Anak }\end{array}$

Usia Dini (PAUD). Jakarta: Badan Litbang Depdiknas.

Depdiknas. 2007. Panduan Pengelola Taman Kanak-Kanak. Jakarta : Badan Litbang.

Peraturan menteri Pendidikan Nasional No. 58. 2009. Standar Pendidikan Anak Usia Dini. Jakarta.

Santosa, P, dkk. 2009. Materi Dan Pembelajaran Bahasa Indonesia SD. Jakarat: Universitas Terbuka
Sidharto,suryati,Rita $\quad 2007$. Pengembangan Kebiasaan Positif. Yogyakarta: Pusat Penelitian Anak Usia Dini Kependidik-an. Vol.9. No. 1 Maret 2011:1-8

Siskandar. 2003. Kurikulum Berbasis Kompetensi Anak Usia Dini.

Slamet, 2007. Dasar-dasar pendidikan anak usia dini. Yogyakarta: Hikayat. Publishing.

Yusuf, Syamsu. 2009. Psikologi Perkembangan Anak Dan Remaja Bandung: PT. Remaja Rosdakarya. 